\title{
The proposed Teaching Excellence Framework (TEF) for UK Universities
}

Dr Dan Berger, University of Hertfordshire d.berger@herts.ac.uk

Professor Charles Wild, University of Hertfordshire c.wild@herts.ac.uk

\begin{abstract}
The role of universities within society has been the subject of constant discussion and conjecture amongst politicians, the public, as well as within the Higher Education (HE) sector itself. However, this issue has come ever more to the forefront of people's minds in recent times due to the comprehensive spending review (CSR), related concerns regarding student fees and public debt, and governmental demands for the increased accountability of Universities in terms of student satisfaction and perceived 'value for money'.
\end{abstract}

The Research Excellence Framework (REF), which replaced the Research Assessment Exercise (RAE), is accepted as a reasonably effective means by which universities, and their researchers, may be assessed periodically and subsequently allocated Quality Research (QR) funding in recognition, as well as to reinforce, research excellence in the HE sector. However, the results of any exercise will be interpreted in a number of ways and, inevitably, has led to claims that the 'teaching' function of universities has become the poor relation to the sector's research agenda.

There have been a number of initiatives which have sought to address this perceived imbalance, and to regulate, monitor or even promote the educational function of universities. Amongst these have been Teaching Quality Assessments, Centres of Excellence in Teaching and Learning (CETLs), and the most recent initiative in the form of the Teaching Excellence Framework (TEF). In many respects, it is hard to challenge the principle that universities should be assessed in the same way for their teaching function as they are for their research activities and outputs. Indeed, the incorporation of 'impact' into the REF offers a seductive promise of similar connections that may be made with teaching in the form of progression, achievement and employability statistics. After all, this is the era of analytics and Big Data, why shouldn't it be used as part of a new system if it is readily available across the HE sector? The authors don't, in principle, disagree with this direction of travel. However, as with any new initiative, time and thought should not only be given to the precise objective of this exercise, but also to the potential pitfalls that may result from making a less than perfect choice. In this respect, the consultation surrounding the current green paper '...' may be likened to the following passage from Lewis Carrol's 'Alice's Adventures in Wonderland: "Would you tell me, please, which way I ought to go from here?" 


\section{Keywords}

Teaching Excellence Framework, Thresholds of Quality, Learning and Teaching, Teaching Quality, Educational Gain

\section{Introduction}

The role of universities within society has been the subject of constant discussion and conjecture amongst politicians, the public, as well as within the Higher Education (HE) sector itself. However, this issue has come ever more to the forefront of people's minds in recent times due to the comprehensive spending review (CSR), related concerns regarding student fees and public debt, and governmental demands for the increased accountability of Universities in terms of student satisfaction and perceived 'value for money'.

The Research Excellence Framework (REF), which replaced the ill-fated Research Assessment Exercise (RAE), is accepted generally as a reasonably effective means by which universities, and their researchers, may be assessed periodically and subsequently based on this assessment, allocated Quality Research (QR) funding in recognition, as well as to reinforce, research excellence in the HE sector. However, the results of any such exercise are subject to interpretation in a variety of ways and, inevitably, it has led to claims that the 'education' or 'teaching' function of universities has become the poor relation to the sector's research agenda, accompanied by claims that academics would prefer to conduct research than teach their students. ${ }^{1}$

There have been a number of initiatives which have sought to address this perceived imbalance, and to regulate, monitor as well as to promote the educational function of universities. Amongst these have been Teaching Quality Assessments, the National Student Survey, and the most recent initiative in the form of the Green Paper entitled 'Fulfilling our potential: Teaching Excellence, Social Mobility and Student Choice'2 and referred to as the Teaching Excellence Framework (TEF) from Jo Johnson.

In many respects, it is hard to challenge the principle that universities should be assessed in the same way for their teaching function as they are for their research activities and outputs. Indeed, the perceived success of incorporating 'impact' into the REF offers a seductive promise of similar connections that may be made with teaching in the form of progression, achievement and employability statistics. After all, this is the era of analytics and Big Data, why shouldn't it be used as part of a new system if it is readily available across the HE sector?

\footnotetext{
${ }^{1}$ Scott.P, (2015), 'Three reasons why the Teaching Excellence Framework won't work', The Guardian, 2 November

2 'Fulfilling our potential: Teaching Excellence, Social Mobility and Student Choice' (November 2015) Higher Education Directorate, Department for Business, Innovation \& Skills, https://www.gov.uk/government/uploads/system/uploads/attachment data/file/474266/BIS-15-623-fulfilling-ourpotential-teaching-excellence-social-mobility-and-student-choice-accessible.pdf
} 
The authors don't, in principle, disagree with this direction of travel. After all, a student should leave university having benefitted from the experience with a qualification that is not only recognized as being of value by employers but also of relevance to the current and future market in which graduates will find themselves. However, as with any new initiative, time and thought should not only be given to the precise objective of this exercise, but also to the potential pitfalls that may result from making a less than perfect choice. In this respect, the consultation surrounding the current green paper '...' may be likened to the following passage from Lewis Carrol's 'Alice's Adventures in Wonderland: ${ }^{3}$

"Would you tell me, please, which way l ought to go from here?"

"That depends a good deal on where you want to get to," said the Cat.

"I don't much care where - "said Alice.

"Then it doesn't matter which way you go," said the Cat."

The era of analytics and Big Data offers the tantalizing opportunity to measure, collate and compare data between universities relating to student retention, progression, achievement on graduation and employability statistics. In addition, there is data relating to the ethnic and gender profiles of student cohorts, information relating to widening participation, statistics relating to student satisfaction at module and programme level, as well as data relating to the student views of individual lecturers. In a perfect world, there is data that covers almost every aspect of a student's time at university. The reality though is that we do not exist within a perfect world. Whilst information, data and statistics are useful, they are only truly helpful when they form part of a more detailed picture.

In this respect, we are Alice at the crossroads. Do we pursue a course that places blind faith in the power of Big Data, that produces percentages, pie charts, traffic light rankings between universities which can be absorbed by the mass media and, only then, ask individual HE institutions to defend their positions afterwards, as per the annual NSS and DLHE results? Or do we develop a system that seeks to understand the underlying culture and ethos of educational provision offered by each individual HE providers, and accept that whilst there are significant overlaps between universities Big Data can, in practice, only go so far in terms of reinforcing a picture, as opposed to driving it?

The question arises as to whether we are faced with two less than ideal choices. The former will be popular, if not with the HE sector, certainly with the central government and the media. It is the path of least resistance, and places the onus on HE institutions to justify their record and the 'value for money' which their past, present and future students receive. The latter path is far more courageous and resource intensive. It requires a considerable level of understanding of the educational process.

\footnotetext{
${ }^{3}$ Caroll, L, (1865) 'Alice's Adventures in Wonderland', 6.45-50
} 
Going back to our earlier analogy, whilst all universities may appear as green apples for the purposes of comparing their educational functions, not all green apples perform the same function; some are for eating whilst others are for cooking. The potential danger with Big Data is that it simply tells you whether one, most probably the eating apple, is more popular than the other. Whilst this is true in and of itself, it is only part of the picture. Furthermore, if it is used as the sole basis for broader decision-making, reliance on Big Data could skew the market to the detriment of other core aspects of the economy. Consequently, we should not rush down a particular path without giving due consideration to the broader implications of the eventual system to be adopted; that would be 'madness' wouldn't it? An additional risk associated with any new system, such as with the Teaching Quality Assessment (TQA) in the past is that 'the management of quality [eventually takes] over from the delivery of quality'. ${ }^{4}$

If one considers the Green Paper, key terms such as 'value for money' or 'what employers want' appear 27 and 35 times respectively, whilst the terms 'teachers' and 'academic' both feature twice, Whilst a great deal is understandably reliant on both choice of language and context, it is interesting to note that the former two terms mirror those used by Harvey and Green ${ }^{5}$ in their discussion of conceptualisations of quality within education, as well as in 'Dimensions of Quality'. ${ }^{6}$ The authors seek to pose the question as to whether a true choice exists or whether a path has already been chosen. Are we predestined to give in to the temptation of Big Data - to know everything - or is there the opportunity to pursue a more refined mechanism that seeks to measure more than simply headline statistics taken in isolation and free from the complexities as outlined in Biggs' '3P' model (1993)? Can we avoid this very different type of apple?

\section{Measurements / Thresholds of quality}

The QAA seeks to make a distinction between standards and quality. It states that a standard represents the level of achievement that a student needs to reach in order to gain an academic award. By contrast, it defines quality as a way of describing 'how well the learning opportunities available to students are managed so as to help them to achieve their award. It is about making sure that appropriate and effective teaching, support, assessment and learning opportunities are provided for students'. ${ }^{7}$

There have been a number of attempts to define the concept and nature of 'quality' within the area of education. ${ }^{8}$ However, one of the most commonly utilised is that provided by Harvey and Green ${ }^{9}$ who suggest that quality should be regarded as a relative concept, not only in terms of meaning different things to different people but

\footnotetext{
4 Underwood.S, (2015) "Reforming quality assurance in higher education." The regulation of higher education, p4

${ }^{5}$ Harvey, L \& Green, D . (1993) Defining quality. Assessment and Evaluation in Higher Education. 18 (1), pp9-34

${ }^{6}$ Graham Gibbs, Dimensions of Quality, September 2010, HEA

${ }^{7}$ Science and Technology Committee: 2012 Chapter 5, para 112

${ }^{8}$ Cheng, Y .C \& Tam, W .M. (1997) Multi-models of quality in education. Quality Assurance in Educatio. 5 (1), pp22-31

${ }^{9}$ Harvey, L \& Green, D . (1993) Defining quality. Assessment and Evaluation in Higher Education. 18 (1), pp9-34
} 
also in relation to processes and outcomes. Gibbs ${ }^{10}$ goes on to note that 'what matters is whether one educational context has more or less quality than another, not whether it meets an absolute threshold standard so that it can be seen to be of adequate quality, nor whether it is reaches a high threshold and can be viewed as outstanding and of exceptional quality, nor whether a context is perfect, with no defects.'

Harvey and Green ${ }^{11}$ go on to group conceptualisations of quality into five categories; exception, perfection, fitness for purpose, value for money, and as transformative. As noted earlier, the latter two categories are of particular interest in the context of the TEF. The notion of 'value for money' is something which lies at the heart of the Green Paper and, many would suggest, appears to be definition of quality driving the government's agenda in this area. The suggestion of quality as being transformative or, put more simply, the 'educational gain' of students during the course of their studies (as opposed to their ultimate educational performance) is also of particular interest for a number of reasons.

First of all, Cambridge University's recent response to the TEF consultation exercise that 'the 'long-reach' aim of universities is to help students grow into thoughtful and critical citizens' as opposed to merely enabling them to become 'earners and consumers', mirrors the authors' stance of the significance and importance of developing students' critical reasoning skills. ${ }^{12}$ Therefore, any measurement of quality must be linked to this aspect of a university education. The other key term used throughout the Green Paper is 'what employers' want' and, again, may be linked with Cambridge's response. The aim of education is to instill more than just subject-specific knowledge or technical ability; it is to develop a student's 'problem-solving, creativity, teamwork and critical thinking', ${ }^{13}$ which are precisely the skills and attributes that employers value. Finally, the notion of quality as being measured in terms of transformative impact is of particular relevance when considering the validity of student judgments of the quality of teaching they have received whilst at University, particularly in relation to another of the government's current measures of quality; the NSS. Student perceptions of what they would like to receive from their lecturers may not always correspond with 'what is known to work in terms of educational effectiveness'. ${ }^{14}$ Equally, student interpretations of the questions being posed not only vary between those of academics and students but also amongst students themselves due to the fact that 'survey questions are too vague to elicit meaningful answers'. ${ }^{15}$

\footnotetext{
${ }^{10}$ Graham Gibbs, Dimensions of Quality, September 2010, HEA, p11

${ }^{11}$ Harvey, L \& Green, D . (1993) Defining quality. Assessment and Evaluation in Higher Education. 18 (1), pp9-34

12 Berger.D \& Wild.C, (2016) 'The proposed Teaching Excellence Framework (TEF) for UK higher education institutions: Enhancing critical reasoning skills to improve the employability of widening participation students', (pending publication)

${ }_{13}$ Morgan.A, .University of Cambridge: Green Paper plans risk 'considerable damage”, Times Higher Education, 25 January 2016

${ }^{14}$ Graham Gibbs, Dimensions of Quality, September 2010, HEA, p11

15 Agrawal.A, Buckley-Irvine.N \& Clewlow.E, 'Is the National Student Survey fit for purpose?' The Guardian, 12 August 2014
} 
What is clear is that education is an extremely complex process and, as such, it is necessary to seek to understand the dimensions of quality within education along with the varied contexts and interactions of these elements. In this regard, the ' $3 \mathrm{P}$ ' model ${ }^{16}$ treats education as a complex system in which the three dimensions of quality (presage, process and product) interact with one another. Biggs' model is seen traditionally as the most effective means of starting to analyse the education environment and focuses on three areas: Presage, Process, and Product. ${ }^{17}$

What is readily apparent is the fact that each and every category is already the subject of data collection by universities or government agencies, including those highlighted in the Green Paper; student retention, graduate employment and the NSS. Data also exists, and is collated annually, for Key Information Set (KIS) which outline information relating to class contact hours, student achievement, average entry tariffs, professional accreditation as well as graduate employability rates. As noted earlier, the era of analytics and Big Data offers the tantalizing opportunity to measure, collate and compare data between universities for all of these areas.

However, whilst statistics are informative, they are only truly useful when they form part of a more detailed, complex and contextualised picture. In reality there is considerable overlap and interaction between the three Ps outlined in Bigg's model which contributes to an extremely complex system. Indeed, there have been attempts to subdivide these areas into more detailed categories ${ }^{18}$ but the reality is that we are far from being able to model the arena of education effectively or usefully. Indeed, the Science and Technology Committee's Report ultimately notes that, in their opinion, the quality of a degree is dependent on all three factors 'to ensure that high quality graduates leave Higher Education with the right skills and knowledge to prepare them for work'. ${ }^{19}$

\section{Conclusions}

In principle, the proposed Teaching Excellence Framework is a commendable idea, insofar as there is a genuine need to ensure that all students from a wide range of backgrounds, attending a wide range of $\mathrm{HE}$ institutions receive the best quality education to which they are entitled. Every University, whether research intensive or not, regards their educational function as central to their mission statements and, as such, is committed to satisfying certain thesholds and standards. In other words, each HE institution confirms that they are an apple and cyclically satisfies the threshold for

\footnotetext{
${ }^{16}$ Biggs, J.B. (1993) 'From theory to practice: a cognitive systems approach', Higher Education Research and Development. 12(1), p73-85

${ }^{17}$ Graham Gibbs, Dimensions of Quality, September 2010, HEA, p11

${ }^{18}$ Finnie, R \& Usher, A . (2005) Measuring the Quality of Post-secondary Education: Concepts, Current Practices and a Strategic Plan. Kingston, Canadian Policy Research Networks; Usher, A \& Savino, M . (2006) A world of difference: a global survey of university league tables. Toronto, Educational Policy Institute. Available from: www.educationalpolicy.org/pdf/world-ofdifference-200602162.pdf [12 August 2010]

${ }^{19}$ Science and Technology Committee: 2012 Chapter 5, para 113
} 
'greenness'. The TEF wishes to go further. It seeks to explore the land of apples, categorising them in terms of colour, texture and flavour and to identify the best ones.

The era of metrics, analytics and BIG Data offers the temptation that this is possible. Its offers a very different apple which will enable the consumer to know everything based on information relating to entry tariffs, student retention and progression, student achievement on graduation and employability statistics. In addition, there is data relating to the ethnic and gender profiles of student cohorts, information relating to widening participation, statistics relating to student satisfaction at module and programme level, as well as data relating to the student views of individual lecturers. There is also data relating to class contact hours, modes of assessment and the professional of programmes. In a perfect world, there is data that covers almost every aspect of a student's time at university.

The reality though is that we do not exist within a perfect world. Whilst information, data and statistics are informative, they are only truly useful when they form part of a more detailed, complex and contextualised picture.

\section{References}

Adams, Stephen (July 17, 2008). "University degree system 'is a farce'". The Telegraph: News. Telegraph Media Group Limited. Retrieved June 3, 2013

Agrawal.A, Buckley-Irvine.N \& Clewlow.E, 'Is the National Student Survey fit for purpose?' The Guardian, 12 August 2014

Berger.D \& Wild.C, (2016) 'The proposed Teaching Excellence Framework (TEF) for UK higher education institutions: Enhancing critical reasoning skills to improve the employability of widening participation students', (pending publication)

Biggs, J.B. (1993) 'From theory to practice: a cognitive systems approach', Higher Education Research and Development. 12(1), p73-85

BIS Committee, 12th Report (2010-12): Government reform of Higher Education (HC 885)

Caroll, L, (1865) 'Alice's Adventures in Wonderland'

Cheng, Y .C \& Tam, W .M. (1997) Multi-models of quality in education. Quality Assurance in Educatio. 5 (1), pp22-31

Finnie, R \& Usher, A . (2005) Measuring the Quality of Post-secondary Education: Concepts, Current Practices and a Strategic Plan. Kingston, Canadian Policy Research Networks. 
'Fulfilling our potential: Teaching Excellence, Social Mobility and Student Choice' (November 2015) Higher Education Directorate, Department for Business, Innovation \& Skills,

https://www.gov.uk/government/uploads/system/uploads/attachment data/file/474266/ BIS-15-623-fulfilling-our-potential-teaching-excellence-social-mobility-and-studentchoice-accessible.pdf

Harvey, L \& Green, D . (1993) Defining quality. Assessment and Evaluation in Higher Education. 18 (1), pp9-34

HEA, Graham Gibbs, Dimensions of Quality, September 2010

Morgan.A, .University of Cambridge: Green Paper plans risk 'considerable damage", Times Higher Education, 25 January 2016

Science and Technology Committee, "Second Report on Higher Education in Science, Technology, Engineering and Mathematics (STEM) subjects, Chapter 5".

Publications.parliament.uk. Retrieved March 11, 2014.

Scott.P, (2015), 'Three reasons why the Teaching Excellence Framework won't work', The Guardian, 2 November

Usher, A \& Savino, M . (2006) A world of difference: a global survey of university league tables. Toronto, Educational Policy Institute. Available from: www.educationalpolicy.org/pdf/world-ofdifference-200602162.pdf [12 August 2010].

Underwood.S, (2015) "Reforming quality assurance in higher education." The regulation of higher education 